\title{
Assessment of the Impact of Next Generation Solvent on DWPF Melter Off-Gas Flammability
}

W. E. Daniel

February 2013

Savannah River National Laboratory Savannah River Nuclear Solutions, LLC Aiken, SC 29808 contract number DE-AC09-08SR22470. 
SRNL-STI-2013-00035

Revision 0

\section{DISCLAIMER}

This work was prepared under an agreement with and funded by the U.S. Government. Neither the U.S. Government or its employees, nor any of its contractors, subcontractors or their employees, makes any express or implied:

1. warranty or assumes any legal liability for the accuracy, completeness, or for the use or results of such use of any information, product, or process disclosed; or

2. representation that such use or results of such use would not infringe privately owned rights; or

3. endorsement or recommendation of any specifically identified commercial product, process, or service.

Any views and opinions of authors expressed in this work do not necessarily state or reflect those of the United States Government, or its contractors, or subcontractors.

\section{Printed in the United States of America \\ Prepared for \\ U.S. Department of Energy}




\section{REVIEWS AND APPROVALS}

AUTHORS:

W. E. Daniel, Engineering Process Development

Date

TECHNICAL REVIEW:

F. G. Smith, III, Process Modeling \& Computational Chemistry

Date

APPROVAL:

C. C. Herman, Manager

Date

Process Technology Programs

S. L. Marra, Manager

Date

Environmental \& Chemical Process Technology Research Programs

E. J. Freed, Manager

Date

SRR Engineering 


\section{EXECUTIVE SUMMARY}

An assessment has been made to evaluate the impact on the DWPF melter off-gas flammability of replacing the current solvent used in the Modular Caustic-Side Solvent Extraction Process Unit (MCU) process with the Next Generation Solvent (NGS-MCU) and blended solvent. The results of this study showed that the concentrations of nonvolatile carbon and hydrogen of the current solvent in the Slurry Mix Evaporator (SME) product would both be about $29 \%$ higher than their counterparts of the NGS-MCU and blended solvent in the absence of guanidine partitioning. When $6 \mathrm{ppm}$ of guanidine (TiDG) was added to the effluent transfer to DWPF to simulate partitioning for the NGS-MCU and blended solvent cases and the concentration of Isopar ${ }^{\circledR} \mathrm{L}$ in the effluent transfer was controlled below $87 \mathrm{ppm}$, the concentrations of nonvolatile carbon and hydrogen of the NGS-MCU and blended solvent were still about $12 \%$ and $4 \%$ lower, respectively, than those of the current solvent. It is, therefore, concluded that as long as the volume of MCU effluent transfer to DWPF is limited to 15,000 gallons per Sludge Receipt and Adjustment Tank (SRAT)/SME cycle and the concentration of Isopar ${ }^{\circledR} \mathrm{L}$ in the effluent transfer is controlled below $87 \mathrm{ppm}$, using the current solvent assumption of 105 ppm Isopar ${ }^{\circledR} \mathrm{L}$ or $150 \mathrm{ppm}$ solvent in lieu of NGS-MCU or blended solvent in the DWPF melter off-gas flammability assessment is conservative for up to an additional 6 ppm of TiDG in the effluent due to guanidine partitioning. This report documents the calculations performed to reach this conclusion. 


\section{TABLE OF CONTENTS}

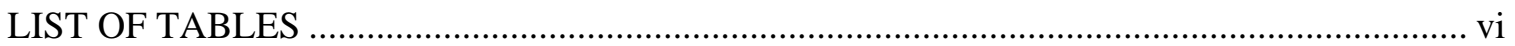

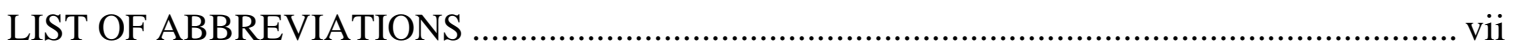

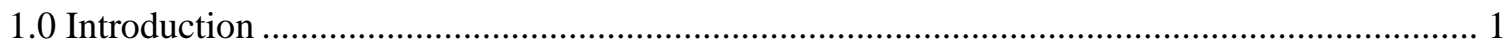

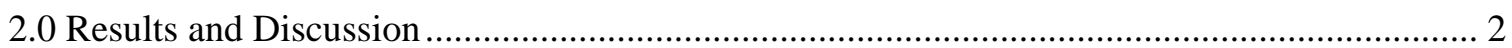

2.1 Solvent Composition and Decomposition ..................................................................... 2

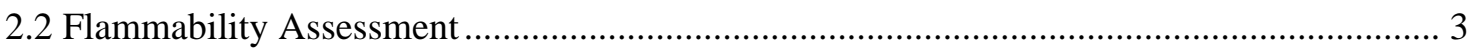

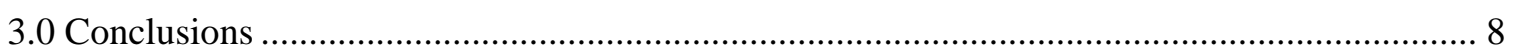

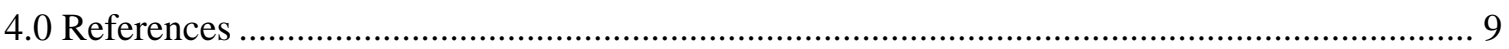




\section{LIST OF TABLES}

Table 2-1. Carbon Sources in Entrained Solvent in Strip Effluent.............................................. 2

Table 2-2. Carbon Sources in Entrained Solvent in Strip Effluent with 6 ppm TiDG.................. 5

Table 2-3. Comparison of Nonvolatile Components of Current Solvent vs. Other Solvents......... 7 


\section{LIST OF ABBREVIATIONS}

$\begin{array}{ll}\text { BOBCalixC6 } & \text { calix[4]arene-bis(tert-octyl benzo-crown-6 } \\ \text { Cs-7SB } & \text { 1-(2,2,3,3-tetrafluoropropoxy)-3-(4-sec-butylphenoxy)-2-propanol } \\ \text { DWPF } & \text { Defense Waste Processing Facility } \\ \text { MaxCalix } & \text { 1,3-alt-25,27-bis(3,7-dimethyloctyl-1-oxy)calix[4]arene-benzocrown-6 } \\ \text { MCU } & \text { Modular Caustic Side Solvent Extraction Unit } \\ \text { MW } & \text { Molecular Weight } \\ \text { NGS } & \text { Next Generation Solvent } \\ \text { SB7b } & \text { Sludge Batch 7b } \\ \text { SME } & \text { Slurry Mix Evaporator } \\ \text { SRAT } & \text { Sludge Receipt and Adjustment Tank } \\ \text { SRNL } & \text { Savannah River National Laboratory } \\ \text { TGA } & \text { Thermogravimetric Analysis } \\ \text { TiDG } & \text { N,N',N”-tris (3,7-dimethyloctyl) guanidine } \\ \text { TOA } & \text { tri-n-octylamine } \\ \text { TOC } & \text { Total Organic Carbon }\end{array}$


SRNL-STI-2013-00035

Revision 0

\subsection{Introduction}

The strip effluent fed to the DWPF Sludge Receipt and Adjustment Tank (SRAT) contains entrained solvent from the Modular Caustic Side Solvent Extraction Unit (MCU) cesium extraction process. The current solvent consists of the diluent Isopar ${ }^{\circledR}$ L with $^{1}$ the following additives:

- $\quad$ 0.007 M BOBCalixC6, calix[4]arene-bis(tert-octyl benzo-crown-6)

- $\quad$ 0.75 M Cs-7SB, 1-(2,2,3,3-tetrafluoropropoxy)-3-(4-sec-butylphenoxy)-2propanol

- $\quad 0.003$ M TOA, tri-n-octylamine

BOBCalixC6 is the cesium extractant, Cs-7SB is the modifier used to increase the solubility of BOBCalixC6, and TOA is used as a suppressor of impurity effects and the ion-pair dissociation as well as to improve stripping. Due to the high volatility $\left(0.5 \mathrm{~mm} \mathrm{Hg}\right.$ vapor pressure at $\left.20^{\circ} \mathrm{C}\right)$ of the diluent Isopar ${ }^{\circledR} \mathrm{L}$, it is assumed to be completely removed during the SRAT processing. Therefore the concentration of Isopar ${ }^{\circledR} \mathrm{L}$ remaining in the SME product is considered to be zero. Only the three nonvolatile components of the solvent listed above remain to carry carbon into the melter and impact melter off-gas flammability.

It has been proposed to replace the current solvent used in MCU with a Next Generation Solvent (NGS-MCU) to increase process efficiency. The proposed NGS-MCU consists of the diluent Isopar $^{\circledR} \mathrm{L}$ with the following additives ${ }^{2,3}$ :

- 0.05 M MaxCalix, 1,3-alt-25,27-bis(3,7-dimethyloctyl-1-oxy)calix[4]arenebenzocrown-6,

- $\quad 0.5 \mathrm{M} \mathrm{Cs-7SB}$, and

- $\quad$ 0.003M TiDG, N,N’,N”-tris (3,7-dimethyloctyl) guanidine

MaxCalix is a cesium extractant, Cs-7SB is a modifier, and TiDG is a suppressing agent. As discussed for the original solvent, the diluent Isopar ${ }^{\circledR} \mathrm{L}$ is assumed completely volatilized during the SRAT process only leaving the three nonvolatile components of the NGS-MCU listed above in the SME product.

It has also been proposed to replace the current solvent used in MCU with a blended solvent. The proposed blended solvent consists of the diluent Isopar ${ }^{\circledR} \mathrm{L}$ with the following additives ${ }^{2,3}$ :

- 0.0465 M MaxCalix,

- $\quad 0.0035$ M BOBCalixC6,

- $\quad 0.5 \mathrm{M} \mathrm{Cs}-7 \mathrm{SB}$,

- $\quad 0.003 \mathrm{M}$ TiDG, and

- $\quad 0.0015$ M TOA

MaxCalix and BOBCalixC6 are the cesium extractants, Cs-7SB is the modifier, and TiDG and TOA are the suppressing agents. As discussed for the original solvent, the diluent Isopar ${ }^{\circledR} \mathrm{L}$ is assumed completely volatilized during the SRAT process only leaving the five nonvolatile components of the blended solvent listed above in the SME product. 
This report assesses the carbon/hydrogen contribution of the proposed solvents as compared with the current solvent with respect to the DWPF Off-gas flammability.

\subsection{Results and Discussion}

\subsection{Solvent Composition and Decomposition}

Table 2-1 lists the chemical composition of the current and proposed NGS-MCU including the chemical formula, molecular weight, and weight percent (wt\%) of the components of the solvents. The wt\% distribution given in Table 2-1 for the current solvent was obtained from the TTQAP for this task ${ }^{4}$ and is based on the nominal compositions listed in the introduction. The nonvolatile constituents of each solvent are italicized in Table 2-1. These nonvolatile constituents for each solvent were blended into a hypothetical "nonvolatile solvent" using the mole percent listed in Table 2-1. The equivalent stoichiometric formulations for these hypothetical "nonvolatile solvents" are shown on the left hand side of Eq. (1) through Eq. (2). Using these equivalent stoichiometric formulations, an equivalent nonvolatile molecular weight can be calculated for each solvent which are shown in Table 2-1. Equations (1) through (2) represent the stoichiometric decomposition of the hypothetical "nonvolatile solvents" to form the most flammable gas mixtures. The high oxygen demand by the solvent carbon is evident from the $\mathrm{CH}_{4}$ and $\mathrm{C}$ decomposition products shown, which are both heavy oxygen consumers and make up nearly $80 \%$ of all carbons in the nonvolatile portion of the current MCU solvent.

Table 2-1. Carbon Sources in Entrained Solvent in Strip Effluent.

\begin{tabular}{|c|c|c|c|c|c|c|}
\hline Solvent & Component & $\begin{array}{l}\text { Chemical } \\
\text { Formula } \\
\end{array}$ & MW & $\mathrm{Wt}^{2}{ }^{2}$ & $\begin{array}{c}\text { Mol\% } \\
\text { Nonvolatile }\end{array}$ & $\begin{array}{c}\text { Nonvolatile Equiv. } \\
\text { MW } \\
\end{array}$ \\
\hline \multirow{4}{*}{ Current } & BOBCalixC6 & $\mathrm{C}_{72} \mathrm{H}_{92} \mathrm{O}_{12}$ & 1149.64 & 0.94 & 0.92 & \multirow{3}{*}{345.842} \\
\hline & Cs-7SB & $\mathrm{C}_{16} \mathrm{H}_{22} \mathrm{~F}_{4} \mathrm{O}_{3}$ & 338.34 & 29.78 & 98.68 & \\
\hline & TOA & $\mathrm{C}_{24} \mathrm{H}_{51} \mathrm{~N}$ & 365.77 & 0.13 & 0.40 & \\
\hline & Isopar $^{\circledR} \mathrm{L}$ & $\mathrm{C}_{11}-\mathrm{C}_{13}$ & 163 & 69.14 & N/A & \\
\hline \multirow{4}{*}{$\begin{array}{l}\text { NGS- } \\
\text { MCU }\end{array}$} & MaxCalix & $\mathrm{C}_{62} \mathrm{H}_{82} \mathrm{O}_{8}$ & 955.31 & 5.70 & 9.03 & \multirow{3}{*}{395.119} \\
\hline & Cs-7SB & $\mathrm{C}_{16} \mathrm{H}_{22} \mathrm{~F}_{4} \mathrm{O}_{3}$ & 338.34 & 20.20 & 90.38 & \\
\hline & TiDG & $\mathrm{C}_{31} \mathrm{H}_{66} \mathrm{ClN}_{3}$ & 516.34 & 0.20 & 0.59 & \\
\hline & Isopar ${ }^{\circ}$ L & $\mathrm{C}_{11}-\mathrm{C}_{13}$ & 163 & 73.90 & N/A & \\
\hline \multirow{6}{*}{$\begin{array}{l}\text { Blended } \\
\text { Solvent }\end{array}$} & MaxCalix & $\mathrm{C}_{62} \mathrm{H}_{82} \mathrm{O}_{8}$ & 955.31 & 5.30 & 8.39 & \multirow{5}{*}{396.194} \\
\hline & BOBCalixC6 & $\mathrm{C}_{72} \mathrm{H}_{92} \mathrm{O}_{12}$ & 1149.64 & 0.48 & 0.63 & \\
\hline & Cs-7SB & $\mathrm{C}_{16} \mathrm{H}_{22} \mathrm{~F}_{4} \mathrm{O}_{3}$ & 338.34 & 20.18 & 90.17 & \\
\hline & TiDG & $\mathrm{C}_{31} \mathrm{H}_{66} \mathrm{ClN}_{3}$ & 516.34 & 0.18 & 0.53 & \\
\hline & TOA & $\mathrm{C}_{24} \mathrm{H}_{51} \mathrm{~N}$ & 365.77 & 0.07 & 0.29 & \\
\hline & Isopar® L & $\mathrm{C}_{11}-\mathrm{C}_{13}$ & 163 & 73.79 & N/A & \\
\hline
\end{tabular}

Current Solvent “Nonvolatiles” Decomposition:

$$
\begin{aligned}
& \mathrm{C}_{16.545} \mathrm{H}_{22.757} \mathrm{O}_{3.071} \mathrm{~F}_{3.947} \mathrm{~N}_{0.004} \rightarrow 5.689 \mathrm{CH}_{4}+6.799 \mathrm{C}+3.071 \mathrm{CO}+ \\
& 0.987 \mathrm{CF}_{4}+0.002 \mathrm{~N}_{2}
\end{aligned}
$$


NGS-MCU “Nonvolatiles” Decomposition:

$$
\begin{aligned}
& \mathrm{C}_{20.243} \mathrm{H}_{27.678} \mathrm{O}_{3.434} \mathrm{~F}_{3.615} \mathrm{Cl}_{0.0059} \mathrm{~N}_{0.018} \rightarrow 6.919 \mathrm{CH}_{4}+8.984 \mathrm{C}+3.434 \mathrm{CO}+ \\
& 0.9038 \mathrm{CF}_{4}+0.00147 \mathrm{CCl}_{4}+0.0088 \mathrm{~N}_{2}
\end{aligned}
$$

Blended Solvent “Nonvolatiles” Decomposition:

$$
\begin{aligned}
& \mathrm{C}_{20.314} \mathrm{H}_{27.790} \mathrm{O}_{3.452} \mathrm{~F}_{3.607} \mathrm{Cl}_{0.0053} \mathrm{~N}_{0.019} \rightarrow 6.947 \mathrm{CH}_{4}+9.012 \mathrm{C}+3.452 \mathrm{CO}+ \\
& 0.9017 \mathrm{CF}_{4}+0.00132 \mathrm{CCl}_{4}+0.0094 \mathrm{~N}_{2}
\end{aligned}
$$

\subsection{Flammability Assessment}

In order to examine the flammability impact of the MCU solvents, several assumptions have to be made. The assumptions used in this flammability assessment are:

1. The concentration of current solvent in the strip effluent fed to DWPF was assumed to be $150 \mathrm{ppm}$. This is the solvent concentration used in the current DWPF flammability calculations. ${ }^{5}$

2. The concentrations of the NGS-MCU and blended solvent in the strip effluent were calculated based on the maximum Isopar ${ }^{\circledR} \mathrm{L}$ concentration of $87 \mathrm{ppm}^{6}$ as follows:

$$
\begin{aligned}
& \frac{87 \mathrm{ppm} \text { Isopar }}{\frac{73.90 \mathrm{wt} \% \mathrm{NGS}-\mathrm{MCU}}{100}}=117.7 \mathrm{ppm} \mathrm{NGS-MCU} \\
& \frac{87 \mathrm{ppm} \text { Isopar }}{\frac{73.79 \mathrm{wt} \% \text { Blended }}{100}}=117.9 \mathrm{ppm} \text { Blended }
\end{aligned}
$$

3. 15,000 gallons of strip effluent (specific gravity $=1.002$ ) are fed to the SRAT per CPC cycle and all of the nonvolatile solvent constituents are transferred to the SME.

4. The SME batch is 5,678 gallons with a specific gravity ${ }^{7}$ of 1.45 .

Using the assumptions above, the amount of additional TiDG (N,N',N"-tris (3,7-dimethyloctyl) guanidine) that can be added to the 15,000 gallon effluent for the NGS-MCU and Blended Solvent cases will be found to stay below the flammability limits for the current solvent.

From assumptions 1, 2, and 3, the mass of solvents added to each SRAT Batch is calculated by:

$$
\begin{aligned}
& \frac{15,000 \text { gal solvent }}{\text { SRAT Batch }} \times \frac{3.7854 \mathrm{~L}}{\mathrm{gal}} \times \frac{1.002 \mathrm{~kg}}{\mathrm{~L}} \times \frac{150 \mathrm{~kg} \text { current solvent }}{10^{6} \mathrm{~kg}}=8.534 \frac{\mathrm{kg} \text { current solvent }}{\text { SRAT Batch }} \\
& \frac{15,000 \mathrm{gal} \mathrm{solvent}}{\text { SRAT Batch }} \times \frac{3.7854 \mathrm{~L}}{\mathrm{gal}} \times \frac{1.002 \mathrm{~kg}}{\mathrm{~L}} \times \frac{117.7 \mathrm{~kg} \mathrm{NGS}-\mathrm{MCU}}{10^{6} \mathrm{~kg}}=6.698 \frac{\mathrm{kg} \mathrm{NGS} \text {-MCU solvent }}{\text { SRAT Batch }}
\end{aligned}
$$




$$
\frac{15,000 \text { gal solvent }}{\text { SRAT Batch }} \times \frac{3.7854 \mathrm{~L}}{\mathrm{gal}} \times \frac{1.002 \mathrm{~kg}}{\mathrm{~L}} \times \frac{117.9 \mathrm{~kg} \text { Blended }}{10^{6} \mathrm{~kg}}=6.708 \frac{\mathrm{kg} \text { Blended solvent }}{\text { SRAT Batch }}
$$

Based on the information above and the calculations outlined below, the ppm of additional TiDG added to the 15,000 gallons of strip effluent with NGS or blended solvent was incremented by 1 ppm starting at $1 \mathrm{ppm}$ to find the maximum value where the flammability limits of the current solvent would still be bounding. The starting $1 \mathrm{ppm}$ is based on a predicted partitioning of $<1.4$ ppm of TiDG in the strip effluent from an ORNL report on the properties of various guanidine suppressors. ${ }^{8}$ The maximum value found was $6 \mathrm{ppm}$ of additional TiDG added to the 15,000 gallons of strip effluent with NGS or blended solvent. The rest of the calculations use this maximum $6 \mathrm{ppm}$ value and then compare the NGS and blended solvent to the current solvent in terms of flammability potential. The new solvent mass per SRAT Batch for the maximum $6 \mathrm{ppm}$ addition of TiDG is calculated by:

$$
\begin{aligned}
& 6.698 \frac{\mathrm{kg} \mathrm{NGS}-M C U \text { solvent }}{\text { SRAT Batch }}+\frac{15,000 \mathrm{gal} \text { solvent }}{\text { SRAT Batch }} \times \frac{3.7854 \mathrm{~L}}{\mathrm{gal}} \times \frac{1.002 \mathrm{~kg}}{\mathrm{~L}} \times \frac{\frac{6}{10^{6}}}{1-\frac{6}{10^{6}}} \frac{\mathrm{kg} \text { TiDG }}{\text { SRAT Batch }}= \\
& 7.039 \frac{\mathrm{kg} \mathrm{NGS} \text {-MCU solvent }}{\text { SRAT Batch }} \\
& 6.708 \frac{\mathrm{kg} \text { Blended solvent }}{\text { SRAT Batch }}+\frac{15,000 \mathrm{gal} \mathrm{solvent}}{\text { SRAT Batch }} \times \frac{3.7854 \mathrm{~L}}{\mathrm{gal}} \times \frac{1.002 \mathrm{~kg}}{\mathrm{~L}} \times \frac{\frac{6}{10^{6}}}{1-\frac{6}{10^{6}}} \frac{\mathrm{kg} \mathrm{TiDG}}{\text { SRAT Batch }}= \\
& 7.049 \frac{\mathrm{kg} \text { Blended solvent }}{\text { SRAT Batch }}
\end{aligned}
$$

Using the new solvent mass from Equation (9) and (10), the carbon source concentrations can be recalculated taking into account the original solvent mass from Equation (7) and (8) and the original concentrations from Table 2-1. For example, the weight percent of TiDG in the NGS-MCU with the maximum 6 ppm addition of TiDG to the strip effluent is calculated by:

$$
\frac{\left[6.698 \frac{\mathrm{kg} \mathrm{NGS}-M C U \text { solvent }}{\text { SRAT Batch }} \times \frac{0.200 \mathrm{wt} \% \mathrm{TiDG}}{100}+\frac{15,000 \text { gal solvent }}{\text { SRAT Batch }} \times \frac{3.7854 \mathrm{~L}}{\mathrm{gal}} \times \frac{1.002 \mathrm{~kg}}{\mathrm{~L}} \times \frac{\frac{6}{10^{6}} \mathrm{~kg} \mathrm{TiDG}}{1-\frac{6}{10^{6}} \text { SRAT Batch }}\right]}{7.039 \frac{\mathrm{kg} \mathrm{solvent}}{\text { SRAT Batch }}}=5.04 \mathrm{wt} \%
$$

The revised weight percent's for TiDG are significantly higher since the $6 \mathrm{ppm}$ addition of TiDG occurs for the entire 15,000 gallons of effluent and does not contain any Isopar ${ }^{\circledR}$ L. Using the logic described above, Table 2-2 lists the chemical composition of the proposed NGS-MCU and blended solvent with 6 ppm TiDG addition* to the strip effluent including the chemical formula, molecular weight, and weight percent (wt\%) of the components of the solvents. 
Table 2-2. Carbon Sources in Entrained Solvent in Strip Effluent with 6 ppm TiDG.

\begin{tabular}{|c|c|c|c|c|c|c|}
\hline Solvent & Component & $\begin{array}{l}\text { Chemical } \\
\text { Formula }\end{array}$ & MW & Wt\%* & \begin{tabular}{|c|} 
Mol\% \\
Nonvolatile*
\end{tabular} & $\begin{array}{c}\text { Nonvolatile Equiv } \\
\text { MW* }\end{array}$ \\
\hline \multirow{4}{*}{$\begin{array}{l}\text { NGS- } \\
\text { MCU* }\end{array}$} & MaxCalix & $\mathrm{C}_{62} \mathrm{H}_{82} \mathrm{O}_{8}$ & 955.31 & 5.42 & 7.86 & \multirow{3}{*}{410.878} \\
\hline & Cs-7SB & $\mathrm{C}_{16} \mathrm{H}_{22} \mathrm{~F}_{4} \mathrm{O}_{3}$ & 338.34 & 19.22 & 78.63 & \\
\hline & TiDG & $\mathrm{C}_{31} \mathrm{H}_{66} \mathrm{ClN}_{3}$ & 516.34 & 5.04 & 13.51 & \\
\hline & Isopar® L & $\mathrm{C}_{11}-\mathrm{C}_{13}$ & 163 & 70.32 & N/A & \\
\hline \multirow{6}{*}{$\begin{array}{l}\text { Blended } \\
\text { Solvent* }\end{array}$} & MaxCalix & $\mathrm{C}_{62} \mathrm{H}_{82} \mathrm{O}_{8}$ & 955.31 & 5.04 & 7.30 & \multirow{5}{*}{411.774} \\
\hline & BOBCalixC6 & $\mathrm{C}_{72} \mathrm{H}_{92} \mathrm{O}_{12}$ & 1149.64 & 0.46 & 0.55 & \\
\hline & Cs-7SB & $\mathrm{C}_{16} \mathrm{H}_{22} \mathrm{~F}_{4} \mathrm{O}_{3}$ & 338.34 & 19.20 & 78.47 & \\
\hline & $T i D G$ & $\mathrm{C}_{31} \mathrm{H}_{66} \mathrm{ClN}_{3}$ & 516.34 & 5.01 & 13.43 & \\
\hline & TOA & $\mathrm{C}_{24} \mathrm{H}_{51} \mathrm{~N}$ & 365.77 & 0.07 & 0.25 & \\
\hline & Isopar® L & $\mathrm{C}_{11}-\mathrm{C}_{13}$ & 163 & 70.22 & N/A & \\
\hline
\end{tabular}

Based on the compositions in Table 2-2, the equivalent stoichiometric formulations for these hypothetical "nonvolatile solvents" and their decomposition to flammable gas are shown in Equations (12) and (13) below:

NGS-MCU with 6 ppm extra TiDG “Nonvolatiles” Decomposition:

$$
\begin{aligned}
& \mathrm{C}_{21.641} \mathrm{H}_{32.659} \mathrm{O}_{2.988} \mathrm{~F}_{3.145} \mathrm{Cl}_{0.135} \mathrm{~N}_{0.405} \rightarrow 8.165 \mathrm{CH}_{4}+9.669 \mathrm{C}+2.988 \mathrm{CO}+ \\
& 0.7863 \mathrm{CF}_{4}+0.0338 \mathrm{CCl}_{4}+0.2027 \mathrm{~N}_{2}
\end{aligned}
$$

Blended Solvent with 6 ppm extra TiDG “Nonvolatiles” Decomposition:

$$
\begin{aligned}
& \mathrm{C}_{21.699} \mathrm{H}_{32.745} \mathrm{O}_{3.004} \mathrm{~F}_{3.139} \mathrm{Cl}_{0.134} \mathrm{~N}_{0.405} \rightarrow 8.186 \mathrm{CH}_{4}+9.691 \mathrm{C}+3.004 \mathrm{CO}+ \\
& 0.7847 \mathrm{CF}_{4}+0.0336 \mathrm{CCl}_{4}+0.2026 \mathrm{~N}_{2}
\end{aligned}
$$

From assumption 4, the mass of a SME batch is calculated by:

$$
\frac{5,678 \mathrm{gal}}{\text { SME Batch }} \times \frac{3.7854 \mathrm{~L}}{\mathrm{gal}} \times \frac{1.45 \mathrm{~kg}}{\mathrm{~L}}=31,165.7 \frac{\mathrm{kg}}{\text { SME Batch }}
$$

Based on the wt\% Isopar ${ }^{\circledR} \mathrm{L}$ compositions in Table 2-1 and the kg of solvent per SRAT Batch found above, the kg of nonvolatiles from the solvents per SME Batch is calculated by:

$$
\begin{aligned}
& 8.534 \frac{\mathrm{kg} \text { current solvent }}{\text { SRAT Batch }} \times \frac{\text { SRAT Batch }}{\text { SME Batch }} \times(1-w t \% \text { Isopar })=\frac{\mathrm{kg} \text { current nonvolatile }}{\text { SME Batch }} \\
& 6.698 \frac{\mathrm{kg} \mathrm{NGS-MCU} \mathrm{Solvent}}{\text { SRAT Batch }} \times \frac{\text { SRAT Batch }}{\text { SME Batch }} \times(1-w t \% \text { Isopar })=\frac{\mathrm{kg} \mathrm{NGS-MCU} \mathrm{nonvolatile}}{\text { SME Batch }} \\
& 6.708 \frac{\mathrm{kg} \text { Blended solvent }}{\text { SRAT Batch }} \times \frac{\text { SRAT Batch }}{\text { SME Batch }} \times(1-w t \% \text { Isopar })=\frac{\mathrm{kg} \text { Blended nonvolatile }}{\text { SME Batch }}
\end{aligned}
$$


Based on the compositions in Table 2-2 and the kg of solvent per SRAT Batch with 6 ppm of TiDG added to the strip effluent, the kg of nonvolatiles from the solvents per SME Batch is calculated by:

$$
\begin{aligned}
& 7.039 \frac{\mathrm{kg} \mathrm{NGS-MCU} \text { solvent }}{\text { SRAT Batch }} \times \frac{\text { SRAT Batch }}{\text { SME Batch }} \times(1-w t \% \text { ISopar })=\frac{\mathrm{kg} \mathrm{NGS-MCU \text {nonvolatile }}}{\text { SME Batch }} \\
& 7.049 \frac{\mathrm{kg} \text { Blended solvent }}{\text { SRAT Batch }} \times \frac{\text { SRAT Batch }}{\text { SME Batch }} \times(1-w t \% \text { Isopar })=\frac{\mathrm{kg} \text { Blended nonvolatile }}{\text { SME Batch }}
\end{aligned}
$$

The calculated mass of the nonvolatile components of the solvents in each SME Batch are shown in Table 2-3. The amount of carbon from the nonvolatile components of the solvents in each SME Batch are calculated by:

$$
\begin{aligned}
& \frac{\mathrm{kg} \text { nonvolatile }}{\text { SME Batch }} \times \frac{1}{\text { Nonvolatile Equiv. } M W} \times \frac{\mathrm{kgmol} \text { nonvolatile }}{\mathrm{kg} \text { nonvolatile }} \times \frac{\mathrm{kgmol} \mathrm{C}}{\mathrm{kgmol} \mathrm{nonvolatile}} \times \frac{12.01 \mathrm{kgC}}{\mathrm{kgmol} \mathrm{C}} \times \\
& \frac{1}{31,165.7 \mathrm{~kg} \mathrm{SME} \mathrm{Batch}} \times \frac{1.0 E 06 \mathrm{ppm} \mathrm{C}}{\frac{\mathrm{kgC}}{\mathrm{kgSMEBatch}}}=\frac{\mathrm{ppm} \mathrm{C}}{\text { SME Batch }}
\end{aligned}
$$

Where the nonvolatile equivalent molecular weight for each solvent is defined in Table 2-1 and Table 2-2 and the kilograms of nonvolatile are defined from Equation (18) and (19). The $\frac{\mathrm{kgmol} \mathrm{C}}{\mathrm{kgmol} \mathrm{nonvolatile}}$ term is defined as 16.545 for the current solvent, 20.243 for NGS-MCU, 21.641 for NGS-MCU with 6 ppm additional TiDG, 20.314 for blended solvent, and 21.699 for blended solvent with 6 ppm additional TiDG based on the stoichiometric equations (1), (2), (3), (12), and (13). The calculated mass of carbon from the solvents per SME Batch is shown in Table 2-3.

The moles of hydrogen per mole of carbon (Moles H/Moles C) for the nonvolatiles in the solvents are shown in Table 2-3. These molar ratios are calculated using the moles defined in the equivalent stoichiometric formulations for each solvent shown in Equations (1) through (3) and (12) and (13).

To calculate the moles of oxygen used for the decomposition of the nonvolatile carbon sources from the solvents, the following decomposition reactions are used:

$$
\begin{aligned}
\mathrm{CH}_{4}+2 \mathrm{O}_{2} & \rightarrow \mathrm{CO}_{2}+2 \mathrm{H}_{2} \mathrm{O} \\
\mathrm{C}+\mathrm{O}_{2} & \rightarrow \mathrm{CO}_{2} \\
\mathrm{CO}+\frac{1}{2} \mathrm{O}_{2} & \rightarrow \mathrm{CO}_{2}
\end{aligned}
$$

Note that the $\mathrm{CF}_{4}$ and $\mathrm{CCl}_{4}$ compounds are considered noncombustible or do not use up oxygen. So for each mole of $\mathrm{CH}_{4}$ decomposed, 2 moles of $\mathrm{O}_{2}$ are used. For each mole of $\mathrm{C}$ decomposed, 1 mole of $\mathrm{O}_{2}$ is used. For each mole of $\mathrm{CO}$ decomposed, 0.5 mole of $\mathrm{O}_{2}$ is used. Using the stoichiometric equations (1), (2), (3), (12), and (13), and the decomposition reactions (21) through (23), the moles of $\mathrm{O}_{2}$ used per mole of $\mathrm{C}$ in the nonvolatile of the solvents can be calculated. For example, for the current solvent: 


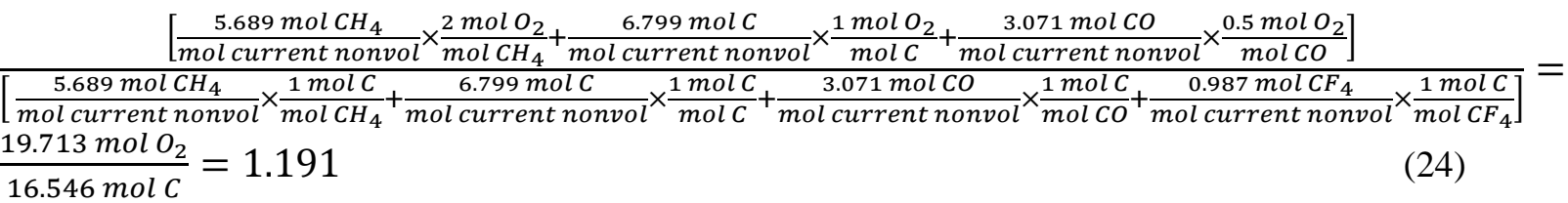

The calculated $\mathrm{O}_{2}$ demand moles per mole of $\mathrm{C}$ for the solvents are shown in Table 2-3.

The next value calculated for the solvents is the total $\mathrm{O}_{2}$ demand per SME Batch. In order to calculate these values, the total moles of $\mathrm{C}$ per SME batch needs to be found using the following equation:

$\frac{p p m C}{S M E \text { Batch }} \times \frac{\frac{1 \mathrm{kgC}}{1.0 E 06 \mathrm{kgSMEBatch}}}{p p m C} \times 31,165.7 \mathrm{~kg} \mathrm{SMEBatch} \times \frac{1000 \mathrm{gC}}{\mathrm{kgC}} \times \frac{\text { gmol C }}{12.01 \mathrm{gC}}=\frac{\text { total gmol C }}{\text { SME Batch }}$

Using Equation (25), the total gmole of C per SME Batch for the current solvent is 126.0, for NGS-MCU is 89.6, for NGS-MCU with 6 ppm additional TiDG is 110.1, for blended solvent is 90.1, and blended solvent with $6 \mathrm{ppm}$ additional TiDG is 110.6. With these values the total $\mathrm{O}_{2}$ demand per Batch are calculated by:

$$
\frac{\text { total gmol C }}{S M E \text { Batch }} \times \frac{{\text { gmol } O_{2} \text { demand }}_{\text {gmol C }}}{\text { Sotal gmol } \mathrm{O}_{2} \text { demand }}
$$

The calculated total $\mathrm{O}_{2}$ gmole demand per SME Batch for each solvent is shown in Table 2-3.

Table 2-3. Comparison of Nonvolatile Components of Current Solvent vs. Other Solvents

\begin{tabular}{|c|c|c|c|c|c|}
\hline $\begin{array}{c}\text { Nonvolatile Solvent in } \\
\text { SME Batch }\end{array}$ & $\begin{array}{c}\text { Current } \\
\text { Solvent }\end{array}$ & NGS-MCU & $\begin{array}{c}\text { NGS- } \\
\text { MCU } \\
\text { with 6 } \\
\text { ppm } \\
\text { TiDG }\end{array}$ & $\begin{array}{c}\text { Blended } \\
\text { Blended } \\
\text { Solvent }\end{array}$ & $\begin{array}{c}\text { Solvent } \\
\text { with 6 } \\
\text { ppm } \\
\text { TiDG }\end{array}$ \\
\hline Mass, kg & 2.63 & 1.75 & 2.09 & 1.76 & 2.10 \\
\hline Carbon, ppm & 48.6 & 34.5 & 42.4 & 34.7 & 42.6 \\
\hline Total Moles C & 126.0 & 89.6 & 110.1 & 90.1 & 110.6 \\
\hline Moles H/Moles C & 1.375 & 1.367 & 1.509 & 1.368 & 1.509 \\
\hline Total Moles H & 173.3 & 122.5 & 166.1 & 123.3 & 167.0 \\
\hline $\mathrm{O}_{2}$ demand Moles/Mole C & 1.191 & 1.212 & 1.270 & 1.213 & 1.270 \\
\hline $\begin{array}{c}\text { Total } \mathrm{O}_{2} \text { demand } \\
\text { Moles/Batch }\end{array}$ & 150 & 109 & 140 & 109 & 141 \\
\hline
\end{tabular}

The key results from Table 2-3 are:

1. The concentration of nonvolatile carbon from the solvent in the SME product is about 29\% lower for the NGS-MCU and blended solvent than that of the current solvent without guanidine partitioning.

2. The H/C molar ratios are slightly lower for the NGS-MCU and blended solvent than that of the current solvent without guanidine partitioning. 
3. The total moles of $\mathrm{H}$ are about $29 \%$ lower for the NGS-MCU and blended solvent than that of the current solvent without guanidine partitioning.

4. The total oxygen demand is about $27 \%$ lower for the NGS-MCU and blended solvent than that of the current solvent without guanidine partitioning.

5. The concentration of nonvolatile carbon from the solvent in the SME product is about $12 \%$ lower than that of the current solvent for the NGS-MCU and blended solvent with the 6 ppm addition of guanidine (TiDG) to the effluent to simulate partitioning.

6. The H/C molar ratios are about $10 \%$ higher than that of the current solvent for the NGS-MCU and blended solvent with the $6 \mathrm{ppm}$ addition of guanidine (TiDG) to the effluent to simulate partitioning.

7. The total moles of $\mathrm{H}$ are about $4 \%$ lower for the NGS-MCU and blended solvent with the 6 ppm addition of guanidine (TiDG) versus the current solvent.

8. The total oxygen demand is about $6 \%$ lower for the NGS-MCU and blended solvent with the 6 ppm addition of guanidine (TiDG) versus the current solvent.

The main reason for the lower nonvolatile carbon content in the NGS-MCU and blended solvent is that the Isopar ${ }^{\circledR} \mathrm{L}$ content is higher in this next generation solvent $(\sim 74 \mathrm{wt} \%)$ versus the existing solvent ( $\sim 99 \mathrm{wt} \%$ ) which leaves less nonvolatile solvent components in the SME product. Considering these results, the next generation solvent (NGS-MCU) and blended solvent should lead to a lower melter off-gas flammability potential than the current solvent. The maximum 6 ppm addition of TiDG to the effluent for either the NGS-MCU or blended solvent should not increase the melter off-gas flammability potential compared to the current solvent.

The reduction in the overall flammability potential due to substitution of the current solvent with NGS-MCU or blended solvent should be relatively small, since the contribution by the solvent to the total organic carbon (TOC) fed to the melter is small, less than $1 \%$ for the baseline Sludge Batch 7b (SB7b) composition used in the latest flammability calculations ${ }^{5}$.

\subsection{Conclusions}

From the results shown in Table 2-3 and the assumptions in the current L1 flammability calculation, it is concluded that the next generation solvent NGS-MCU and blended solvent would produce slightly less flammable conditions in the melter off-gas than the current solvent. As shown in Table 2-3, the total moles of carbon and hydrogen from the next generation solvent (NGS-MCU) and blended solvent for up to $6 \mathrm{ppm}$ of guanidine (TiDG) addition to the strip effluent are less than those of the current solvent. As a result, the total oxygen demand for the next generation solvent (NGS-MCU) and blended solvent for up to $6 \mathrm{ppm}$ of TiDG addition to the strip effluent is also shown to be lower than that of the current solvent. Therefore, the existing flammability calculations for Sludge Batch $7 b^{5}$ based on the current solvent composition and concentration are bounding if the assumptions used to make this determination for NGS-MCU and blended solvent remain valid. 


\subsection{References}

1. Klatt, L.N., Birdwell, Jr., J.F., Bonnesen, P.V., Delmau, L.H., Foote, L.J., Lee, D.D., Leonard, P.A., Levitskaia, T.G., Maskarinec, M.P., and Moyer, B.A., "Caustic-Side Solvent Extraction Solvent-Composition Recommendation,” ORNL/TM-2001/258, Oak Ridge National Laboratory, Oak Ridge, TN, January 2001.

2. Samadi, A., "DWPF Melter Off-Gas Flammability Calculation with Next Generation Solvent (NGS) and 50/50 NGS/Current Solvent Blend,” HLW-DWPF-TTR-2011-00023, Rev. 1, Savannah River Remediation, Aiken, SC, December 6, 2012.

3. Samadi, A., “Testing for ARP/MCU NGS Project-DWPF,” HLW-DWPF-TTR-201000045, Rev. 1, Savannah River Remediation, Aiken, SC, December 5, 2011.

4. Newell, J. D., W. E. Daniel, “Task Technical and Quality Assurance Plan for Evaluation of DWPF Impacts of the Revised Next Generation Solvent, ," SRNL-RP-2012-00888, Rev 1, Savannah River National Laboratory, Aiken, SC, February 2013.

5. Choi, A.S., "DWPF Melter Off-Gas Flammability Assessment (Sludge Batch 7b)”, XCLC-S-00164, Rev. 7, Savannah River National Laboratory, Aiken, SC, August 2011.

6. Shafer, A. R., "Waste Acceptance Criteria for Sludge, ARP, and MCU Process Transfers to 512-S and DWPF (U),” X-SD-G-00008, Rev. 9, Savannah River Remediation, Aiken, SC, April 2012.

7. Pareizs, J.M., and Lambert, D.P., "Data and Observations from the SB7b Qualification SRAT and SME Cycles," SRNL-L3100-2011-00141, Rev. 0, Savannah River National Laboratory, Aiken, SC, July 19, 2011.

8. Moyer, Bruce A., Lætitia H. Delmau, Nathan C. Duncan, Dale D. Ensor, Talon G. Hill, Denise L. Lee, Benjamin D. Roach, Frederick V. Sloop, Jr., and Neil J. Williams, "Recommended Guanidine Suppressor for the Next-Generation Caustic-Side Solvent Extraction Process,” ORNL/TM-2012/625, Oak Ridge National Laboratory, Oak Ridge, TN, January 2013. 


\section{Distribution:}

E. N. Hoffman, 999-W

C. C. Herman, 999-W

D. K. Peeler, 999-W

M. E. Stone, 999-W

J. D. Newell, 999-W

D. P. Lambert, 999-W

J. R. Zamecnik, 999-W

R. K. Leugemeors, 992-5W

S. L. Marra, 773-A

S. D. Fink, 773-A

D. R. Click, 773-A

C. M. Jantzen, 773-A

F. M. Pennebaker, 773-42A

W. R. Wilmarth, 773-A

D. T. Herman, 735-11A

P. R. Jackson, 703-46A

C. J. Bannochie, 773-42A

T. B. Peters, 773-42A

A. S. Choi, 773-42A

F. G. Smith, 703-41A

J. F. Iaukea, 704-30S

J. W. Ray, 704-S

D. C. Sherburne, 704-S

J. P. Windham, 704-30S

J. M. Bricker, 704-27S

T. L. Fellinger, 704-26S

A. Samadi, 704-27S

E. W. Holtzscheiter, 704-15S

P. J. Ryan, 210-S
E. J. Freed, 704-56H

D. J. Martin, 241-152H

R. H. Spires, 241-156H

E. A. Brass, 249-8H

J. P. Schwenker, 766-H

K. H. Subramanian, 241-156H 